УДК 902.01:572.029

DOI: $10.18384 / 2310-676 \mathrm{X}-2020-5-89-105$

\title{
THE „I” OF A WARRIOR. SOCIAL COMPLEXITY AND CULTURAL RECOGNITION OF WARRIOR VIRTUES IN THE CORDED WARE CULTURE
}

\author{
R. Skrzyniecki, W. Skrzyniecka \\ Adam Mickiewicz University in Poznań \\ 1 Wieniawskiego ul., Poznań 61-712, Poland
}

\begin{abstract}
Aim. The aim of this paper is to elaborate a contemporary approach to warriors in archaeology. This particular type of social identity has been sufficiently researched and described in cultural anthropology. However, despite the abundance of information, the recognition of this phenomenon in the debate concerning prehistoric societies has been by no means satisfactory. Therefore, an attempt to provide new interpretations, incorporating various types of interdisciplinary data, must be made. Methodology. One of the ways to better comprehend the essence of warriorhood is to emphasize its universal "core", consisting of a set of physiological reactions to confrontation and social mechanisms covering mutual relations between warriors and other members of a society they belonged to. As a social figure of great importance, a warrior was entangled in a vast network of social relations, which constituted his/her social being. Taking that into account, it is mandatory to study not only material symbols of martial prowess, such as weapons or anthropomorphic figurines, but also the so-called contextual background, including sex, age of weapon-wielders, burial customs attributed to them, as well as their relations to community members buried without attributes of war. This particular goal is often difficult to achieve, mostly due to poor preservation of skeletons or elusive and ambiguous character of social differences displayed in burial ritual. Nevertheless, few cultural traditions from the pre-state era in prehistory offer an invaluable field for this kind of research. The Corded Ware culture is undoubtedly one of them. It puts a strong emphasis on virility and martial prowess, by transcending these values from the world of the living into domain of the dead. Therefore, it will constitute the focal point of the presented idea of warriorhood.

Results. The authors' intention was to emphasize the fact that, despite its spatio-temporal variety, the phenomenon of warriorhood is characterized by a number of unique features, which occur universally in many cultures all over the world.

Research implications. The approach to warriorhood presented in this paper combines the socioanthropological background with the analysis of archaeological data in order to provide a more subject-oriented line of interpretation.
\end{abstract}

Keywords: Corded Ware culture, warriorhood, social identity, weaponry, skeletal injuries

\section{ЛИЧНОСТЬ ВОИНА. СОЦИАЛЬНАЯ СТРАТИФИКАЦИЯ И ОЦЕНКА ВОИНСКИХ ДОБЛЕСТЕЙ В МИРЕ КУЛЬТУР ШНУРОВОЙ КЕРАМИКИ}

\section{Р. Скржинецкий, В. Скржинецка}

Познаньский университет имени Адама Мицкевича

61-712, г. Познань, ул. Венявского д. 1, Польша

\section{Аннотация}

Цель. Разработать современный подход к изучению воинской идентичности в археологии и попытаться дать новую интерпретацию этого феномена.

\footnotetext{
(c) СС ВY Р. Скржинецкий, В. Скржинецка, 2020.
} 
Процедура и методы. В исследовании использованы социально-антропологический и междисциплинарный подходы для анализа археологических данных.

Результаты. Установлено, что, несмотря на пространственно-временное разнообразие, феномен воинственности характеризуется рядом конкретных, уникальных черт, которые встречаются повсеместно во многих культурах по всему миру.

Теоретическаяи/или практическая значимость. Результаты исследования позволяют более предметно-ориентированно интерпретировать френомен воинской идентичности.

Ключевые слова: культура шнуровой керамики, воинская идентичность, социальная идентичность, вооружение, травмы скелета

\section{Introduction}

The presence of weaponry in some prehistoric burials has attracted researchers' attention for at least seven decades, and probably even earlier [7, pp. 126-139]. Because of the lack of textual evidence, as well as often elusive \& ambiguous nature of burial ritual, there is no unified approach towards its interpretation. The debate on this matter is unchangeably polarized [36, pp. 449-470] albeit one particular term seems to represent a common ground. This keyword, or rather a key figure, is a warrior. But who is he (or she), exactly? In other words, what does it mean to be a warrior and whether such information can be accessed through archaeological record?

According to a general definition, warrior is a person whose vocation is warfare. $\mathrm{He}$ (or she) engages in actual, physical activity of fighting. In contrast to conscripted soldiers, warriors are not subordinate to any superiors and usually fight for their own, individual purposes. Their everlasting desire to achieve more and more glory often ends with violent death. Therefore, as stated by $\mathrm{P}$. Clastres [8, pp. 305-307], warriorhood could be compared to a lethal burden which only chosen are brave enough to carry.

\section{Tripartite definition of warriorhood}

Taking into account the complex and interdisciplinary nature of warriorhood, it is proposed that it should be examined in at least three different aspects or dimensions: physiological, social and cultural.

\section{Physiology and psychology of fighting}

The first dimension encompasses warrior's physical and psychological reactions to battle conditions. In other words, it represents an attempt to conceptualize feelings and emotions warriors encounter on their "warpath" and also the way those affect their physicality.

As some researchers claim, human beings are anatomically adapted to the instrumental use of violence. They developed a precise grip necessary for the effective use of throwing weapons. Their wide field of sight facilitates detection of threats and enables an acute assessment of distance to the target. Finally, upright posture along with slender constitution and relatively long legs allow to cover long distances in relatively short time [31, pp. 47-54]. But the true mastery in warriorhood lies not in anatomical predispositions, but in the comprehension of one's physiology and the ability to control it.

The direct experience of a battle usually triggers various reactions, or rather physiological states, which are controlled by a human nervous system. When an individual founds himself in a life-threatening situation, his sympathetic nervous system (SNS) begins to take over. Heart starts to beat faster than normal, and adrenaline and norepinephrine are being released. The individual systematically loses the ability to fully control their movements, which poses a serious threat for an inexperienced warrior, as it decreases one's martial proficiency. People who face the enemy for the first time sometimes experience even more severe reactions, such as nausea, temporal loss of hearing and sight, 
as well as paralysis [13, pp. 114-134]. However, these physiological limitations could be effectively mitigated by high-repetitive weapon training in simulated battle conditions, such as duels. A long process of adaptation to fighting grants better control of physiological excitation, and therefore higher combat effectiveness. It means that true weapon mastery could only be achieved by a narrow group of people meeting certain economic conditions allowing them to invest most of their lifetime into highly sophisticated training [29, pp. 188-202]. Therefore, the nascence of economic and social inequality probably played a major role in the development of a professional warrior class in the past [40, pp. 813-827].

What is more, it is scientifically proven that using different types of weaponry may affect the level of willingness to kill [12, p. 98]. The longer the distance between the killer and his victim, the easier the decision to eliminate the enemy. It happens so because individual traits of the target are blurred and hardly recognizable, and therefore the perception of one's humanity is limited. Generally, it is easier to dispatch an enemy using a bow, than, for instance, an axe or a mace. The reasons for it are manifold: apart from psychological background briefly mentioned above, the risk of receiving a killing blow from an unsuspecting individual hit by an arrow is significantly lower than in close-combat encounter. Moreover, many warriors are unwilling to expose themselves to the enemy arrows in order to shorten the distance to their targets and attack them with their hand-weapons. This tactic is almost impossible to incorporate in pre-state societies, where the lack of institutionalized military leadership usually prevents the execution of orders and therefore hinders the cooperation between diversified units on the battlefield [31, pp. 1-18]. It is believed that pre-Bronze Age war parties utilised primarily ambushes and surprise attacks and relied heavily on their bows and arrows rather than clubs and axes. Only with the rise of social stratigraphy and all its socio-economic after-effects the mastery in using such sophisticated weapons as swords became possible [40, pp. 813-827].

\section{Social dimension of warriorhood}

The second aspect of being a warrior relates to the issues associated with internal organisation and obligations towards society. It covers various mechanisms of interaction, such as structure and hierarchy of warrior institutions, rules of competition and cooperation, as well as attitude towards the Other, i.e. enemy. For instance, an individual might be considered a warrior after reaching certain age threshold or fulfilling a specified task, such as taking an enemy's scalp [8, p. 298]. There were also warrior societies in prehistory, where warriorhood was not granted, but rather "inborn", as it formed an integral part of an elite social status [44, pp. 515528]. In many pre-state communities being a warrior meant additional social privileges [8, p. 302]. However, bellicose individuals were often treated with mistrust and isolated from the social life. As G. Dumézil implied, all who devoted their lives to warlike profession ended as double-beings, entrapped between the good and evil side of morality [9, pp. 105-111]. Their might and prowess were commonly revered, but often feared and dismayed at the same time; uncontrolled lust for violence and disdain for social rules could easily turn them from heroes and saviours to the worst predators.

Therefore, communities with warrior institutions were forced to develop social mechanisms of control and security to minimize the risk of being wiped out and subdued by their own, bellicose kin [8, pp. 297-298]. Warriors mostly fight for glory, and glory constitutes a foundation of their prestige [23; 34]. However, the latter is an arbitrary value administered by the community. It is socially profitable and desired, but in order to achieve it a warrior must willingly expose oneself to constant evaluation. What is more, prestige is never permanent. It actually depends on warrior's actions. One's exploitswere broadly discussed and evaluated by the members of a community and on this basis deemed more or 
less glorious. Every other achievement must be greater than the previous, or prestige will be gradually lost. Eventually warriors become addicted to community's evaluations and fall into an on-going struggle to achieve more and more glory by embarking on more and more life-threating tasks. In the end, every war-devoted individual must embrace his final destiny, i.e. the completion of an ultimate deed which will grant him immortality through death. This is the main sorrow of a pre-state warrior, as P. Clastres put it in his magnificent Archaeology of Violence [8, p. 311].

It is also important to properly address the place of a warlike way of life in the social milieu of prehistoric communities. Origins of warriorhood are often discussed in a broader perspective regarding the process of institutionalisation of violence [42]. Researchers mostly agree that some types of its organized forms, e.g. raids and massacres, occurred in Neolithic or even earlier [41, pp. 145-165; 11, pp. 112-131]. But, as Rick Schulting [35, pp. 24-26] states, it was merely a war without warriors. In other words, being a warrior at that time was not a profession or vocation, but rather a role every able-bodied man had to fulfil when the need arose. In case of central Europe, this situation changed presumably at the turn of the IV and III millennia [37, pp. 94-96]. This period saw major ideological changes, which are, to some degree, reflected in archaeological record. One of them, i.e. the custom of placing weapons in male burials, deserves particular attention.

It was noticed that incorporation of weaponry into the burial ritual in the $3^{\text {rd }}$ millennium BC was somehow associated with reduction of skeletal trauma, best visible when compared to earlier Neolithic samples. One of the most reasonable explanations utilizes R. Kelly's hypothesis of social substitutability [20]. In general, in egalitarian societies lives of people belonging to competing populations have the same value. As a result, killing a random enemy is considered a sufficient "payback" for a murder, even if the victim was not an actual killer. This rule has gradually lost its importance in the course of the $3^{\text {rd }}$ millennium $\mathrm{BC}$, most probably as a result of growing social inequalities. Life of particular individuals, belonging to privileged groups, had grown in value, which in turn disturbed the previously maintained social balance. Every offence, assault and especially murder that affected member of a privileged group had to be properly avenged. The only way to achieve this was to offend, assault or kill the victim's counterpart from the hostile group. As a result, distribution of violence has become restricted to people of particular social rank, presumably associated with combat. The emergence of "warrior burials" and decrease of skeletal trauma are therefore linked together.

\section{Cultural dimmension. Weapons to display, virtues to commemorate}

The last, cultural dimension is represented by means of emphasizing and commemorating warriorhood through material culture. It is also the most archaeologically accessible aspect of identity under discussion. As for the two former dimensions, they represent a necessary context for understanding the latter.

One of the longest discussed matters in funerary archaeology addresses the degree to which material objects buried with an individual "reflected" one's identity [28, pp. 223$235 ; 16$, pp. 327-379]. It is likely that among illiterate societies of prehistoric Europe grave goods were used to display and therefore emphasize values and beliefs of great importance, especially to the mourners. On the more individual level, they could as well represent powerful statements about true or idealized identity of their "owner" [39, pp. 167-176; 47, p. 185]. On the one hand, archaeologists might deal with personal belongings considered essential for their extraordinary value or utility. It is possible that an object was precious to an individual because it represented a part of one's identity which was considered prestigious by its "owner", as well as other members of community. On the other hand, an item or a whole set of funerary offerings could be used to impose a whole new identity 
on the deceased. Therefore, the nature of relations between individual and his or her offerings may be metonymic or metaphoric [ 45 , p. 394]. In the first case, particular categories of grave goods are associated with one's social roles and related responsibilities. Alternatively, the posthumous identity may be manipulated by the mourners by using objects with symbolic meaning. A suggestive example of this custom is represented by child burials furnished with weaponry or other categories of material culture usually restricted for adults [51, pp. 341-351; 50].

The idea of transferring weaponry into the funerary domain is at least 6500 years old and was documented among the communities of Hamangia-Varna cultural circle from the Balkan Peninsula [19, pp. 278-280]. It was also known in different parts of Carpathian zone, as well as Central Europe [1; 38, pp. 875-889; 14]. However, this custom was mostly abandoned during the first half of the $4^{\text {th }}$ millennium BC. Its renaissance is dated to the threshold of the $4^{\text {th }}$ and $3^{\text {rd }}$ millennia $\mathrm{BC}$ and associated with the emergence of new cultural phenomena stimulated by the contact between the Eastern European cattle herders and farming communities of the Old Europe.

One of the most up-to-date narratives dealing with the spread of this new warrior tradition might be used as a plausible introduction to this section. An organised collective of bellicose iuvenes [32, p. 345], belonging to the Eastern European Yamnaya culture, constitutes its focal point. Encumbered by social restrictions, they developed an idea of a one-way expedition westward in order to acquire land to inhabit and space to establish their own social order. Leadership was naturally granted to the bravest and most fearsome warriors with an ability to attract large numbers of their peers. A hope for a better future and a sense of camaraderie bound these men together and their martial experience ensured them military superiority over farmers of Old Europe. According to Kristian Kristiansen and his colleagues, members of those warrior groups practiced exogamy, most probably by kidnapping women from villages they encountered. Due to their limited numbers, the newcomers were eventually incorporated [absorbed?] into local societies, but probably still maintained the memory of their warlike past. A new cultural phenomenon, that is Corded Ware culture (later CWC), emerged and, judging by its origin, celebration of warriorhood constituted an important part of its ideology. In the next part of the paper, different approaches to war-related virtues and the way they were "immortalized" through the CWC burial ritual, will be discussed.

\section{Approaches to warriorhood in chosen zones of the Corded Ware culture ecumene}

The issue of warrior ideology and its emanations among local European communities sharing the Corded Ware tradition was discussed in detail in doctoral thesis of one of the authors. Its central assumption was that both social and cultural dimensions of warriorhood, albeit elusive and in most part non-material, can be accessed and reconstructed through the analysis of particular archaeological and biological characteristics of burials [37]. This approach was influenced by the work of Quentin Bourgeois and Eric Kroon [3; see also Fig. 1], who analysed approx. 1100 burials from the so-called western part of the CWC [15, pp. 83-123] and identified recurring patterns regarding the presence or absence, as well as location of different categories of grave goods in graves of female and male individuals. According to their interpretation, weaponry was one of the most sex-dependent types of funerary gifts, which indicates the social recognition, and therefore ideological importance of warlikerelated activities in the Corded Ware society.

In order to develop a more detailed approach to the matter, the Authors' assumptions were compared to the burial customs of the chosen CWC communities from the Oder and Dniester interfluve, i.e. Małopolska \& Lublin Uplands,Kańczuga Heights and the Sokal Ridge (Fig. 2). 
ISSN 2072-8360 Вестник Московского государственного областного университета. Серия: История и политические науки 2020 / № 5

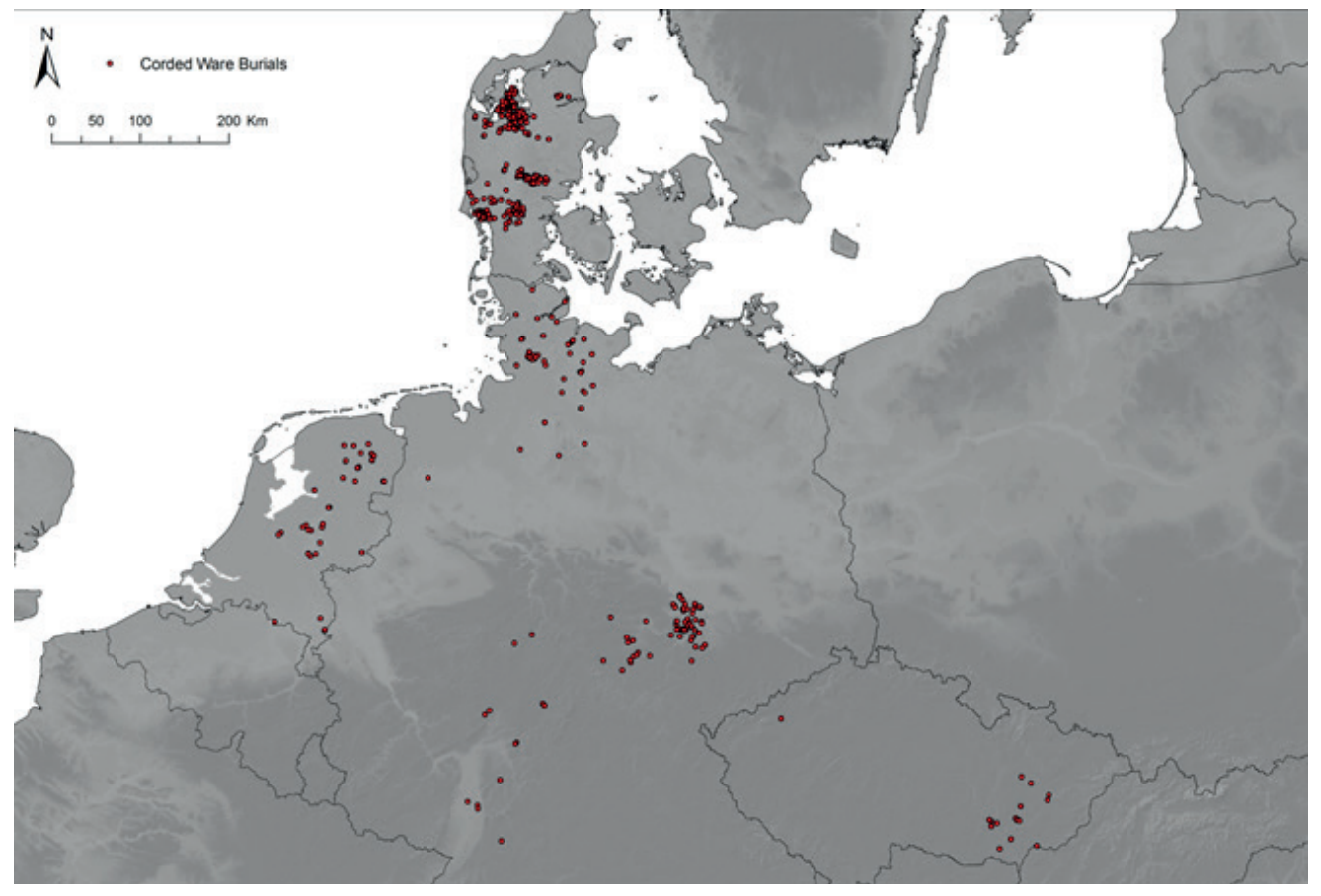

Fig. 1. CWC cemeteries included in the sample collected and analysed by Bourgeois and Kroon. Source: Bourgeois and Kroon 2017.

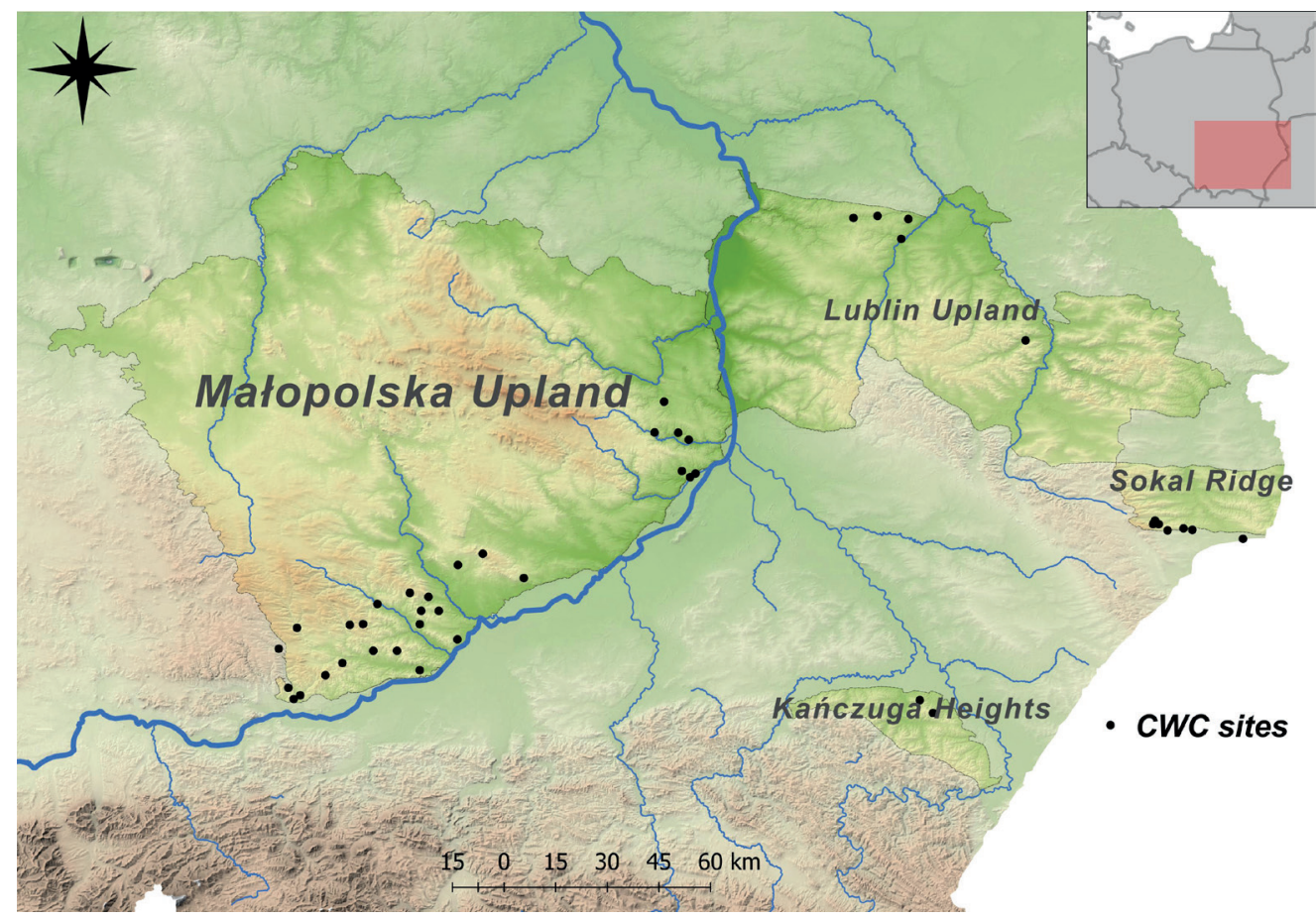

Fig. 2. Geographical range of selected cemeteries from the eastern part of the CWC ecumene. Source: the authors' data. 


\section{Boldly embracing the "New". Warriors among Corded Ware people of Małopolska Upland}

The region in question is widely known for its abundance of skeletal burials associated with the Corded Ware tradition [17; 51; 24]. Significant amount of data, as well as relatively good state of bone preservation offers favourable conditions for the analysis of relations between biological (sex and age) and cultural (body orientation, limbs' arrangement, types of equipment and its location on the bottom of the burial pit) characteristics of the deceased [37, pp. 185-199]. As in the so-called western zone, weaponry was almost exclusively deposited in graves of males. What is more, all weapon-wielders were buried in a particular position, that is on their right-hand side with heads towards south and faces turned to the east. The dominant age category was maturus, although few cases of weaponry associated with individuals of pre-adolescent age were also documented.
Similarly to the areas studied by Bourgeois and Kroon [3], a stone battle axe with a shaft-hole was probably the most iconic weapon of a CWC warrior from Małopolska Upland. Itemsof this kind were found exclusively in burial pits with right-hand sided interments. Due to the absence of material remains of bows, the incorporation of this type of weaponry into the funerary sphere cannot be confirmed. Nevertheless, many graves contained non-organic arrowheads, mostly made of flint. Flint axes, although having potential for self-defence or assault purposes, were not considered specialized tools of war, although there is still some controversy over their possible function [51; 5, pp. 55-64]. On the one hand, those items were deposited in graves of men and women alike. On the other, only men buried on their right-hand side were interred with two or more flint axes. In addition, "warrior axes" were often larger, heavier, and better crafted than specimens found in women and non-combatants' graves [2, pp. 293-306].

\section{Małopolska Upland}
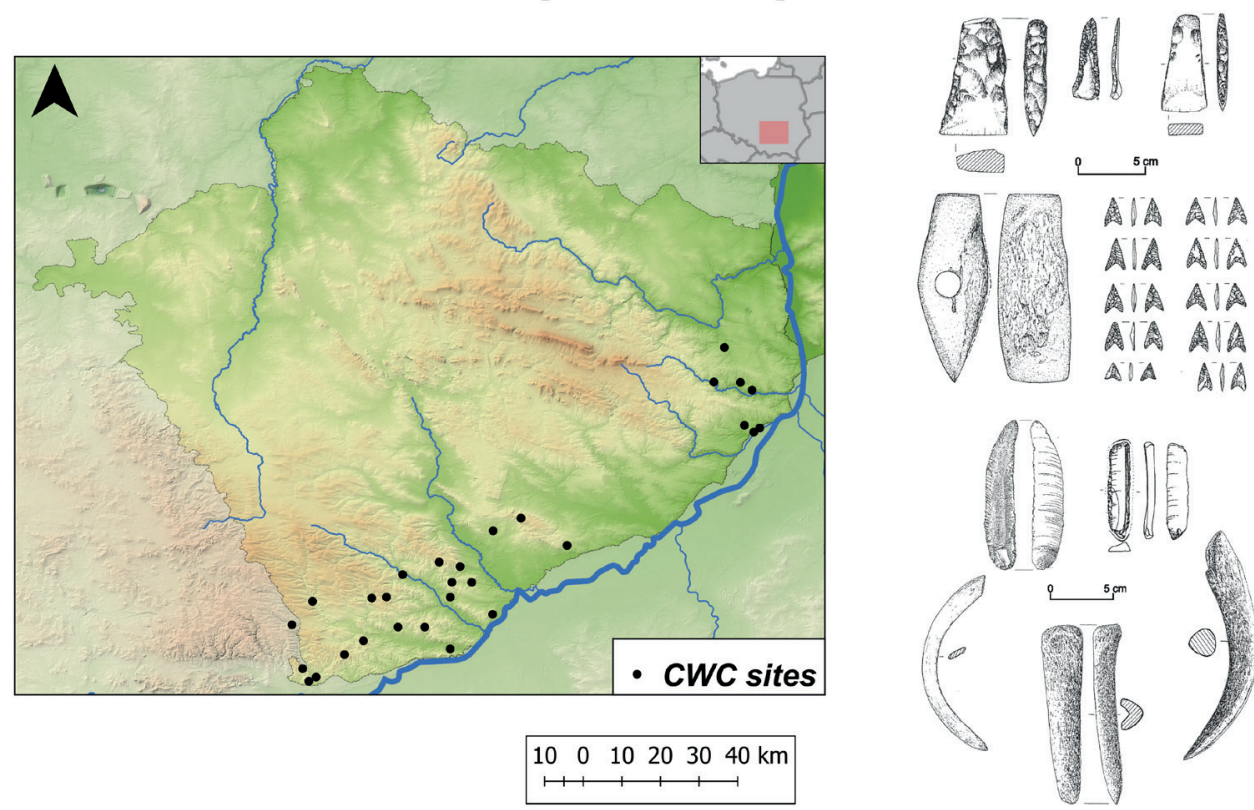

Fig. 3. Location of cemeteries with CWC warrior graves from Małopolska Upland and a selection of objects from their inventory. Source: Compiled by the authors according to various works. 
Apart from weaponry, warrior's equipment included a considerable array of tools made of bone, flint and stone. Some of those objects, such as bone chisels, boar tusks, antler and bone batons, large flat whetstones, flint strikers and ample collections of flint half-products (probably a part of arrowmaker's kit), were almost exclusively deposited in graves of males buried on their right-hand side. It is therefore possible that they constituted a part of a metonymic representation of activities associated with warriorhood.

It is important to emphasize that customs related to the re-creation of warriorhood in the funerary sphere were gradually changing over time. The most notable difference between Małopolska Upland and Corded Ware settlements lying more to the west is the growing importance of long-distance weapons. It is especially evident in the $2^{\text {nd }}$ half of the $3^{\text {rd }}$ millennium $\mathrm{BC}$, when local communities of South-Eastern Poland intensified their contacts with people occupying areas between Dniester and Dnieper rivers. From that period the approach to warriorhood in the CWC ecumene, previously rather uniform in its core principles, had begun to diversify and slowly evolved on its eastern margins into more Bell Beaker-like affirmation of archery.

However, the association between warrior identity and elitism was still in its infancy. In contrast to the culture of warlords, characteristic for the upcoming archaeological epoch, warriors of the Corded Ware culture were most probably revered for their individual prowess and skill, but not for their social superiority [37, pp. 495-527].

\section{Respect for- or the rejection of the ways of the fathers? Local differences in celebration of warrior virtues in different areas of South-Eastern Poland}

From the analysis of archaeological data, it appears that warrior ideal in the whole area of interest was conceptualized according to a set of commonly-shared rules, like an association of military prowess and masculinity, or right-hand-sided orientation of the individual's body. However, there is also a considerable degree of variety in local posthumous celebrations of warriorhood, which is especially evident in terms of quality and quantity of deposited grave goods, along with their placement in the burial pit.

For instance, CWC communities of the Sokal Ridge [26, pp. 137-144; see also Fig. 4] only partially participated in the transition from close-combat to archery-based concept of warriorhood. Like in the West, stone battle-axe remained the most iconic, and therefore important symbol of power and military prowess. On the contrary, the number of lithic arrowheads found in funerary contexts is relatively low when compared to the Małopolska Upland. There are also no direct indications of using flint axes as a substitute for a stone battle-axe. Moreover, the association between weaponry and particular type of tools is far less marked. This situation is similar to that from the end of the $2^{\text {nd }} /$ beginning of the $3^{\text {rd }}$ chronological phase in the Małopolska Upland [37, pp. 512-513]. The absence of weaponry in children's burials suggests that this particular type of warriorhood was celebrated in a metonymical, rather than metaphorical way.

The approach to warriorhood among CWC communities of the Lublin Upland (Fig. 5) represents a case similar to that of the Małopolska Upland, as indicated by the custom of transferring arrows, as well as parts of arrowmaker's kit into the funerary sphere [18, pp. 509-532]. Another feature worth mentioning is the presence of peculiar weapon sets consisting of two flint axes and arrows. Similar combinations of weaponry were documented in warrior graves dated to the sub-phase IIIB and unearthed on the Vistula's left bank. In addition, an association of weaponry with particular types of tools, i.e. bone chisels, boar tusks and bone/antler batons is also evident. The absence of weaponry in graves of children was previously documented for the Sokal Ridge. At the same time weapons were placed in graves of senilis individuals. Therefore, it is likely that one's social rank established during lifetime didn't 


\section{Sokal Ridge}
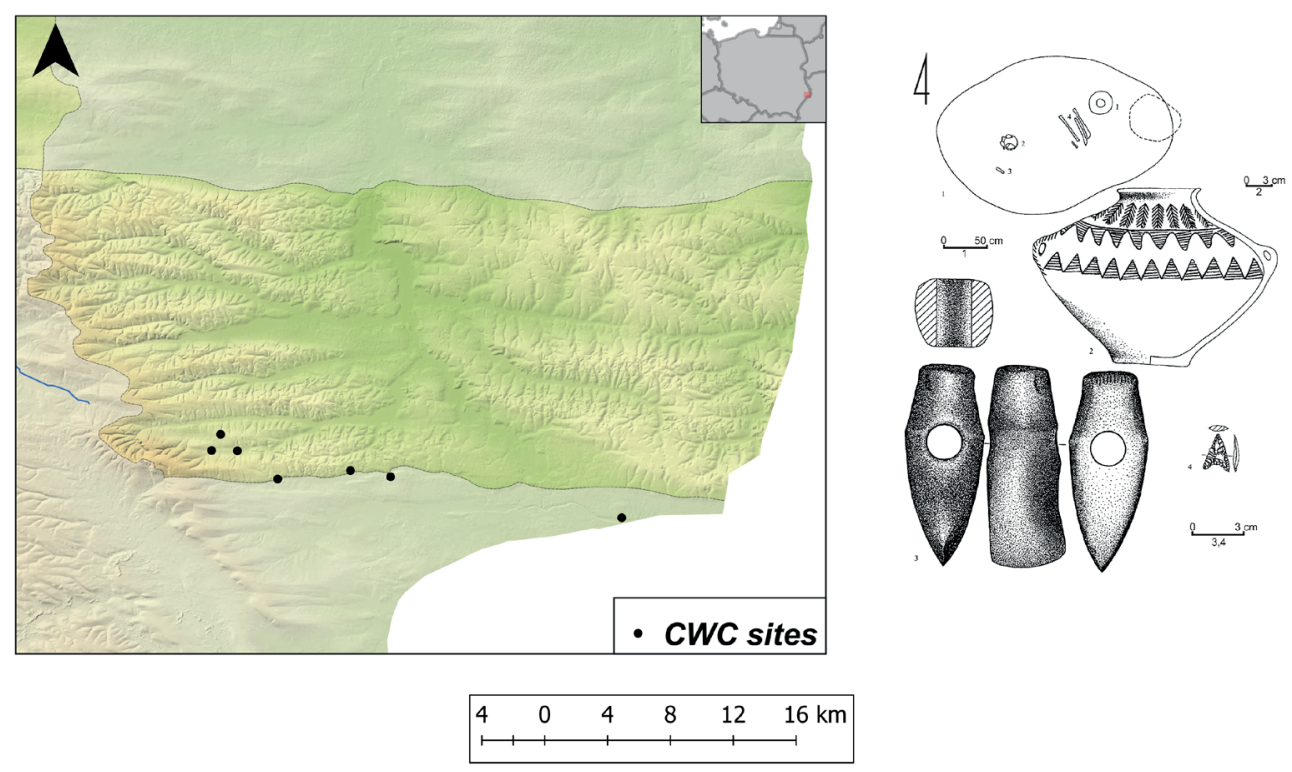

Fig. 4. Location of CWC sites from the Sokal Ridge and a typical inventory from a warrior's grave. Source: Compiled by the authors according to Machnik et al. 2009.

\section{Lublin Upland}
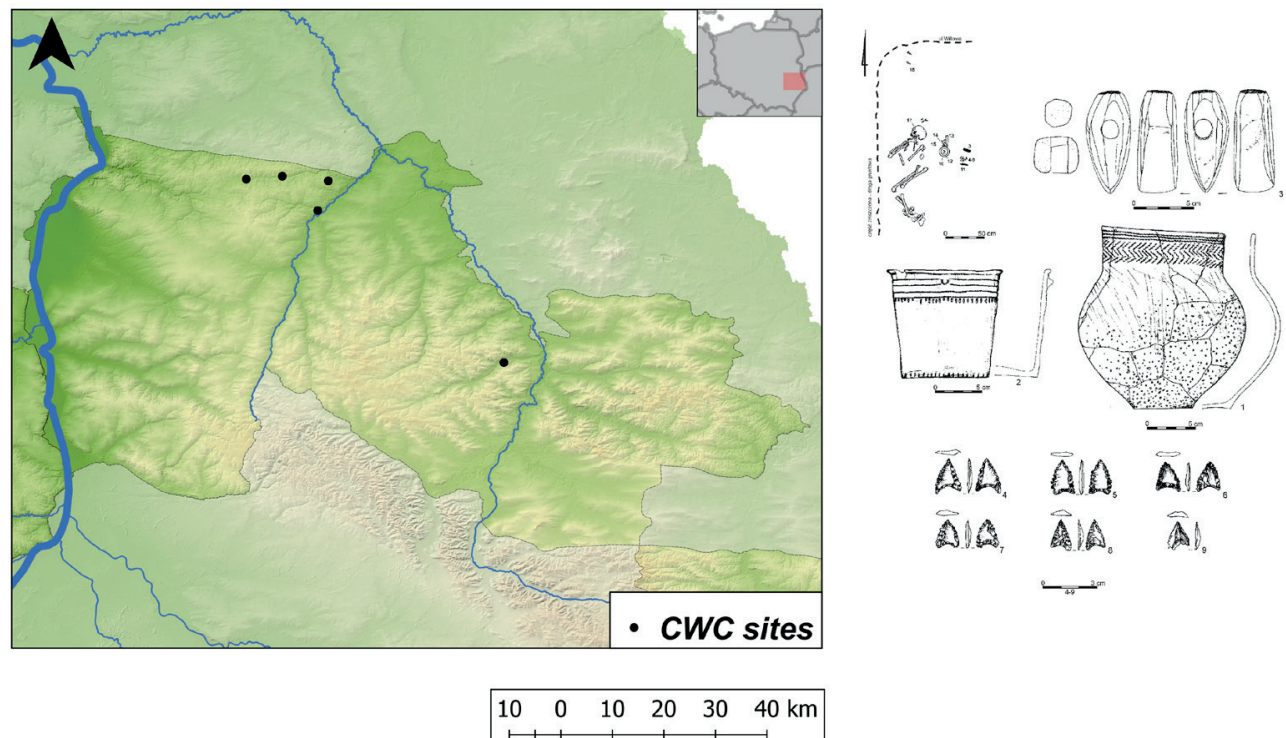

Fig. 5. Location of CWC sites from Lublin Upland and a selection of equipment from a warrior's grave. Source: Compiled by the authors according to Jarosz et al. 2016. 
lost its actuality with age, as was the case in Vikletice, Moravia [48; 49].

Similarly to Małopolska and Lublin Uplands, dead warriors from the region of Carpathian Foothills, also known as Kańczuga Heights (Fig. 6), were interred with stone battle axes and arrows. What is more, one of the graves from Szczytna, site 6, contained an extraordinary shaft-hole battle axe made of arsenic bronze [17, pp. 44-46]. The custom of placing more than one flint axe in the burial pit, characteristic for later phases of the CWC development in South-Eastern Poland, is also present. In two cases the deceased were buried with a full warrior set, consisting of a stone battle-axe, arrows and two axes made of flint. In addition, one of the aforementioned weapon-wielders was given a large flat whetstone, which represents a peculiar combination of old (stone battle axe, whetstone) and new (archer's toolkit, two flint axes) material symbols of warriorhood and other associated activities [37, pp. 516-519].
Contrarily to the Sokal Ridge and Lublin Upland, weaponry was also placed in graves of pre-adolescents, which suggests more metaphorical dimension of warrior identity: two young individuals of infans age were interred with smaller, meticulously shaped battle-axes adjustedto their size. However, this by all means symbolic representation does not include archer's equipment. This rule was also followed by the CWC communities fromMałopolska Upland. Given these examples, it might be concluded that battleaxes functioned as a material symbol of the distinct, social group privileged to carry and display their weapons, while bows represented more pragmatic and lethal way of warring, restricted only to the actual warriors.

In the discussed case, presence of weaponry seems to be associated more with biological sex, than age of the deceased. The custom of placing stone battle-axes next to the pre-adolescents suggests that warriorhood was an important, but rather symbolic than

\section{Kańczuga Heights}
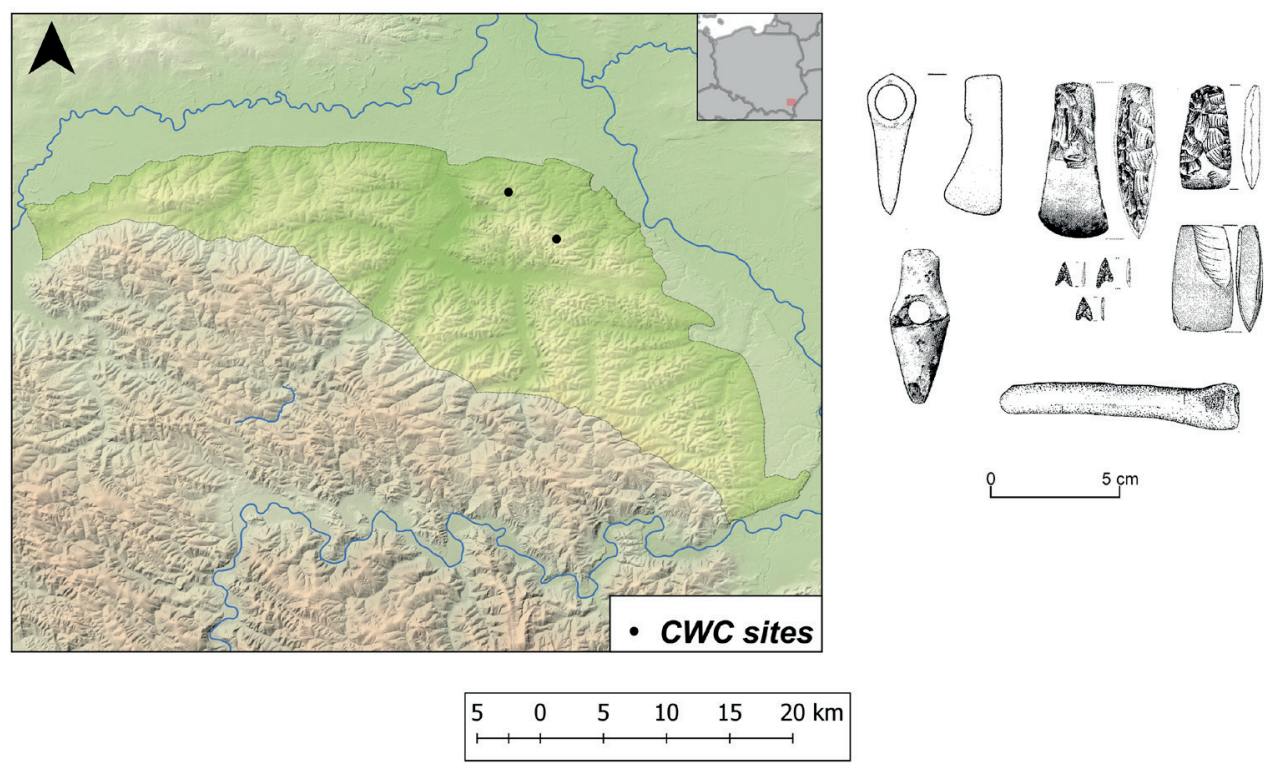

Fig. 6. Location of the largest CWC cemeteries from Kańczuga Heights and a selection of equipment from a warrior's grave. Source: Compiled by the authors according to Hozer et al. 2017. 
actual, part of collective identity of a particular social group. If one takes into account that limited number of females from Szczytna were also buried with very rich inventory, it might be assumed that some CWC communities from the region in question were internally diversified according to a particular social rank system, as was suggested by $\mathrm{H}$. Vandkilde in her study of the Vikletice cemetery in Moravia [45, pp. 393-422].

Fairly large number of prestigious grave goods made of metal might be a result of intensified contacts with communities of the Steppe zone. The most spectacular example of a richly furnished warrior grave is the object no. 4 from Szczytna, site 6 [17, pp. 3847]. It contained an arsenic bronze shaft-hole battle-axe and a copper tool for flint processing, as well as four pieces of metal jewellery, non-organic remains of archer's kit and previously mentioned flint half-products for arrow-making. Quite surprisingly, a man buried with such remarkable gifts was a young individual of adultus age. Judging by his equipment, he must have played an important role in his community. The presence of weaponry and metal adornments indicates that his exceptional status was related to the ideal of warriorhood. On the other hand, it may as well represent an important step into the elitisation of warriorhood, which occurred in a fully developed form in the succeeding age of bronze [46, pp. 37-63].

\section{Warriors in the West. General remarks on ways of celebrating warriorhood in the western zone of the CWC settlement zone}

Before proceeding to the final assessment of the coherence of the CWC warriorhood in its wider geographical scope, a brief summary of its western part must be presented. It is based on the study of Bohemian CWC funerary rites [4; 48; 49; 21, pp. 191-208]; as well as the data published by Bourgeois and Kroon [3].

The burial ritual of the CWC communities from Bohemia was gender-differentiated, with males buried on their right-hand- and women on their left-hand side. Some particular types of grave goods, such as bone chisels, metal tools and stone axes, were deposited only in pair with weapons $[21 ; 48$; 49]. The presence or absence of weaponry was sex-dependent. However, similarly to the Małopolska Upland, part of male population was interred according to different rules, i.e. on a left-hand side and without attributes of war. There are, though, some striking differences, and an almost total lack of archer's equipment is without doubt one of the most intriguing. Moreover, the symbolic significance of close-combat is emphasized by the presence of additional categories of arms, i.e. stone maceheads.

Warriorhood in Bohemia appears to be related to the particular age span stretching from iuvenis to maturus [48, pp. 129-140; 49]. The lack of weaponry designed for middle-range combat might be an important hint on the actual methods of fighting. Bows were most likely considered tools, while stone battle-axes and maces functioned as the main symbols of martial prowess. Some researchers claim that their extraordinary significance actually reflects the duel-like nature of CWC warfare. Similar customs were recorded for modern pre-state societies [6], as well as Mycenaean military organisations of the late Bronze Age [29, pp. 188-202]. The purpose of this mode of interaction is, of course, extremely difficult to determine. It could be a way of establishing internal hierarchy among young warriors, as well as a method of settling down matters without unnecessary bloodshed. Needless to say, expertise gained in such controlled duels was invaluable during encounters with real enemies.

As for the western and northern part of the CWC range weaponry was also placed only in graves of males buried on their righthand side. This particular feature appears to be universal in the whole CWC ecumene. Stone battle-axe was the primary symbol of warriorhood and its symbolic significance was additionally emphasized by placing the weapon in front of the upper part of the 
body of the deceased. This specific custom is also evident in the Małopolska Upland and adjacent areas, although the battle-axe was usually located behind the individual, at the level or slightly above his arms [37, pp. 412-420]. More surprisingly, flint axes from Bourgeois and Kroon's database were located in the same zone of the burial pit as stone battle-axes. This practice bears some resemblance to that from the Małopolska and Lublin Uplands, where flint axes were sometimes deposited in graves instead of a stone battle-axe. However, these objects were usually placed in other, less representative zones of the burial pit, often in the vicinity of tool-like objects intended for everyday use [37, p. 412-420]. Another major difference is the lack of archer's equipment, characteristic also for the previously discussed groups from Bohemia. Most likely the bow was considered a hunting weapon, well suited for shooting game, but not humans. However, burials of the victims from Eulau [27] clearly show that ranged weapons were used for killing people in the time when Corded Ware tradition was still present.

\section{Facing the Enemy. An insight into the Corded Ware ways of fighting}

Remains of arrows and large deposits of flint half-productsi ntended for arrow-making constituted an important part of posthumous warrior image among CWC communities from Vistula and, most likely, also the Dnieper basin. According to a metonymic interpretation of warrior equipment, objects interred with the deceased were connected to personhood and therefore reflected certain part of one's social identity. A steady increase in numbers of middle-range weaponry deposited in CWC graves from South-Eastern Poland during the second half of the $3^{\text {rd }}$ millennium BC might indicate the occurrence of changes both in ideological, as well as practical approach to warriorhood. A significant number of examples demonstrating the socio-ideological importance of archery comes from late Yamnaya and Catacomb cultures funeral contexts [33]. Despite considerable geographical distance, communities from the Małopolska Upland, as well as other adjacent regions, were affected by the Steppe tradition and adopted new ideal of manhood and power, epitomized by the expertise in archery and other associated activities, such as flint processing, and probably also hunting.

Incorporation of archer's equipment into the funerary sphere clearly indicates that effective use of this weapon was considered one of the important aspects of idealized image of manhood. What is more, some burials from the South-Eastern Poland bear traces of arrow wounds, which obviously suggests that bows, apart from their symbolic role, were also actively used in real combat. One of the cases of skeletal trauma was identified in a female burial from large, flat cemetery in Żerniki Górne, site 1. Among the pelvis bone of an adult woman a single flint arrowhead was found. This observation demonstrates that both males and females were treated as potential targets.

Similar association between weaponry interred with the deceased and the character of skeletal trauma could be observed in Germany and Bohemia. Skulls of some adult males bore traces of blunt trauma, located predominantly on the left side of their parietal bones. It is likely that they took part in ritualized duels, during which contestants attacked each other with heavy implements such as stone axes or maces. According to Neubert et al. [30, pp. 217-224], the purpose of this activity was not to kill, but rather to stun an opponent, presumably in order to gain prestige and confirm or renegotiate one's social position. Taking into account all presented data, it might be assumed that the difference in means of commemoration of warrior identity in Western and Eastern zones of the CWC settlement were to some degree related to the nature of actual fighting. Use of bows, as well as the presence of possible female victims indicate, that warfare in SE Poland was less ritual and probably more brutal. This observation is particularly interesting when compared to R. Schulting's idea of eneolithic warriorhood, which, in 
his opinion, marks the transition between voluntary and professional organisation of warrior's craft. It seems that CWC communities from Eastern Europe were under the influence of the previously mentioned Steppe cultural traditions, and adjusted their combat techniques to warlike and aggressive neighbours. The killing of women also suggests that the rule of social substitutability could have been partially restored.

\section{Discussion}

Comparative analysis of burial rituals from the discussed regions of the CWC ecumene demonstrates that customs associated with celebration and commemoration of warriorhood were not uniform. Limited numbers of archer's equipment in burials from Denmark, Germany and Bohemia stand in contrast to its large quantity recorded in graves from SE Poland. However, the incorporation of middle-range weaponry into the funerary sphere became widespread slightly before or shortly after the beginning of the $2^{\text {nd }}$ half of the $3^{\text {rd }}$ millennium BC. Male burials from the earlier period did not contain arrows and were predominantly furnished with stone battle-axes. It appears that between 2800 and 2600 BC warrior identity and its funerary representations were more coherent. After that period, the older, closecombat oriented pattern of warriorhood was still present in the west, but not in the east.

The change that occurred in the conception of warrior's identity in SE Poland is difficult to interpret. The oldest barrow graves of the CWC did not contain any symbols of military prowess, which bears some resemblance to the description of the funerary customs of the oldest Yamnaya migrants published by Kristiansen et al. On the other hand, no evidence of direct Yamnaya migration to the areas of today's SE Poland have been found so far, which weakens the allochtonic line of interpretation.

It is striking that the "explosion" of military symbolism in the funerary sphere occurred in the second half of the $3^{\text {rd }}$ millennium BC. During that time, a major change in mortuary rituals took place. Older customs, which emphasized the dominant role of adult male headmen-patriarchs were replaced with more "liberal" approach, in which individuals of both sexes and all age categories were granted the right for being interred after death. However, a great emphasis was put on the differences between male and female burials, not only in terms of body position, but also assembling of grave goods. This rule does not pertain to the group of adult males interred on their left-hand side. Despite the constant growth of archaeogenetic and bioarchaeological data, the meaning of this peculiar practice still remains obscure. Further assumptions on this matter are possible only from the broader, cross-cultural perspective.

Some male individuals from North American indigenous tribes deliberately renounced their male responsibilities in order to live a life of berdache - a two-spirit being free from restrictions and able to benefit both from male and female social roles. This social category was proposed as a possible explanation for the presence of similar burials among the CWC communities from Bohemia [48, pp. 129-140; 43, pp. 285-293]. In case of SE Poland, it does not appear to be adequate, mostly because of a complete lack of grave goods that could be associated with masculine activities, such as hunting, flint processing, warring, etc. This observation leads to an assumption, that those individuals, as well as women, were presumably excluded from certain social and, perhaps, also economic activities. The latter possibility seems to be of particular interest. During the second half of the $3^{\text {rd }}$ millennium $\mathrm{BC}$, CWC communities from SE Poland, and especially from Małopolska Upland, underwent changes in settlement patterns. The appearance of large cemeteries of flat graves indicate the growth of stability, possibly associated with rising importance of agriculture in contrast to the previous domination of animal husbandry, or even pastoralism [25, pp. $137-$ 144]. Certain groups of men accustomed to the old ways of living were still responsible for animal rearing, and therefore maintained 
the idealized pattern of manhood based on ideas of power and warrior prowess [10, pp. 26-27]. Others were engaged in different economic activities, probably also taken up by women, and, in consequence, could not share the social and symbolic identity of their male counterparts. The considerable growth of quantity, as well as quality of weaponry and associated grave goods deposited in warrior graves could represent an ideological reaction of pastoralists for the previously mentioned re-introduction of agriculture. Reaction aimed at emphasizing their social and ideological distinctiveness, especially in contrast to individuals who did not share their activities and beliefs. The actuality [22, pp. 15-32] of social identity of a warrior, as well as other associated roles, might have also increased as a response for threat represented by pastoralists from Eastern Europe, who, due to the lack of natural borders, were able to penetrate regions of SE Poland. The growing presence of traumata associated with arrow wounds demonstrates that the nature of warfare changed from ceremonial to more lethal, presumably as a consequence of adaptation to more effective fighting techniques utilized by the communities of the Steppe zone.

\section{Afterword}

The approach to warriorhood presented in this paper combines socio-anthropological background with the analysis of archaeological data in order to provide a more subject-oriented line of interpretation. Author's intention was to emphasize the fact, that despite its spatio-temporal variety, the phenomenon of warriorhood is character- ized by a number of unique features, which occur universally in many cultures all over the world. It is an experience firmly rooted in our species' physiology that appears to remain unchanged for the last tens of thousands of years. From the anthropological point of view, warrior virtues among the prestate societies revolve around the economy of glory. This arbitrary value constituted a powerful factor in social relations, especially in non-centralized political systems [31]. Having that knowledge, the researcher is able to go beyond simple qualitative and quantitative analysis of material objects; from one properly asked question to another, one gradually acquires deeper understanding of the foundations of the conflict in question, and eventually the way it affects all social actors engaged in the process. In order to reconstruct social identity without textual information, all possible threads must be taken into account. Spatial relations between the deceased and their "possessions" represent just "a tip of an iceberg". Patterns of collective violence, and therefore bellicose behaviour, are embedded in: subsistence and its susceptibility for changing climate conditions; social organisation of the group under study; types, amount and access to strategic resources; potential competition and, finally, ethnical and cultural distance to neighbours. These are very general issues, but the logic behind their entanglement constitutes a key to understanding how the physicality of violence was ascended to a new, ideological level and eventually became an essential part of new, social identity.

Статья поступила в редакиию 29.05.2020

\section{REFERENCES}

1. Bognár-Kutzián I. The Copper Age Cemetery of Tiszapolgár-Basatanya. Budapest, Akadémiai Kiadó, 1963. 352 p.

2. Borowska J., Budziszewski J. Włodarczak P. Grób kultury ceramiki sznurowej ze stanowiska 18 w Snopkowie, pow. Lubelski. In: Schyłek neolitu na Wyżynie Lubelskiej. Warszawa, Instytut Archeologii i Etnologii Polskiej Akademii Nauk, 2016, pp. 293-306.

3. Bourgeois Q., Kroon E. 2017. The impact of male burials on the construction of Corded Ware identity: Reconstructing networks of information in the 3rd millennium BC. Plos one. Available at: https://doi. org/10.1371/journal.pone.0185971 (accessed: 03.04.2020). 
4. Buchvaldek M., Koutecký D. Vikletice, einschnurkeramisches Gräberfeld, Praehistorica III. Prague, Universita Karlova, 1970, pp. 95-96.

5. Budziszewski J., Włodarczak P. Die schnurkeramischen Beile aus den kleinpolnischen Gräbern. In: H.-J. Beier H.J. Einicke R., Biermann E. (eds) Varia Archaeologica 7. Dechsel, Axt, Beil\& Co-Werkzeug, Waffe, Kultgegenstand ?Aktuellesaus der Neolithforschung, Beiträgezur Ur- und FrühgeschichteMitteluropas. Langenweissbach, Beier\&Beran. ArchäologischeFachliteratur, 2011, vol. 63, pp. 55-64.

6. Chagnon N. Noble Savages. My Life Among Two Dangerous Tribes - The Yanomamö and the Anthropologists. New York-London-Toronto- Sydney-New Delhi, 2013, pp. 247-279.

7. Childe V.G. War in Prehistoric Societies. In: The Sociological Review, 1941, no. 33, pp. 126-39.

8. Clastres P. Archaeology of Violence. Semiotext, 1994, pp. 279-323.

9. Dumézil G., Hiltebeitel A. The Destiny of the Warrior. Chicago, University of Chicago Press, 1970, pp. $105-111$.

10. Eliade M. Historia wierzeń i idei religijnych. Warszawa, Instytut Wydawniczy Pax, 1988, vol. 1, pp. 26-27.

11. Ferguson R.B. The Prehistory of War and Peace in Europe and the Near East. In: War, Peace, and Human Nature: The Convergence of Evolutionary and Cultural Views. Oxford, Oxford University Press, 2013, pp. 112-131.

12. Grossman D. On Killing. The Psychological Cost of Learning to Kill in War and Society. Boston-New York-London, Back Bay Books, 1996, pp. 5-141.

13. Grossman D. On combat: The psychology and physiology of deadly conflict, in war and in peace. Millstadt, IL, Warrior Science Publications. 2004, pp. 1-403.

14. Grygiel R. The Neolithic and Early Bronze Age in the Brześć Kujawski and Osłonki Region. Łódź, Fundacji Badań Archeologicznych Imienia Profesora Konrada Jażdżewskiego, 2008. vol. 2, part 2, pp. 97-118.

15. Haüsler A. Bemerkungen zu den östlichen Regionalgruppen der schnurkeramischen Becherkulturen. In: Jahresschrift fur mitteldeutsche Vorgeschichte, 2014, vol. 94, pp. 83-123.

16. Heyd V. Families, Prestige Goods, Warriors \& Complex Societies:Beaker Groups of the 3rd Millennium cal BC Along the Upper \& Middle Danube. In: Proceedings of the Prehistoric Society, 2007, vol. 73, pp. 327-379.

17. Hozer M., Machnik J., Bajda-Wesołowska A. Groby kultury ceramiki sznurowej i domniemane kultury mierzanowickiej w Szczytnej, pow. Jarosław - źródła, analiza, wnioski. In: Nekropolie kultury ceramiki sznurowej z III tys. przed Chr. w Szczytnej na Wysoczyźnie Kańczuckiej, Via Archaeologica Ressoviensia vol. 12, Rzeszów. 2017, pp. 7-130.

18. Jarosz P., Libera J., Włodarczak P. Schyłek neolitu na Wyżynie Lubelskiej. Kraków, Instytut Archeologii i Etnologii Polskiej Akademii Nauk, 2016, pp. 257-380.

19. Kadrow S. The Early Copper Age: socio-cultural process in modern sociological interpretation. In: Analecta Archaeologica Ressoviensia, 2011, vol. 4, pp. 265-302.

20. Kelly R. Warless Societies and the Origin of War. Ann Arbor, University of Michigan, 2000, pp. 41-163.

21. Kolař J. Idealized World or Real Society? Social Patterns of Corded Ware Culture in Moravia (Czech Republic). In: Transitional Landscapes? The 3rd Millennium BC in Europe. Proceedings of the International Workshop "Socio-Environmental Dynamics over the last 12,000 Years: The Creation of Landscapes III (15th - 18th April 2013)" in Kiel. Bonn, 2016, pp. 191-208.

22. Korostelina K. V. Social Identity as Social Phenomenon and Scientific Concept. In: Social Identity and Conflict. Structures, Dynamics and Implications. Palgrave Macmillan US, 2007, pp. 15-32.

23. Lincoln B. 1987. War and Warriors: An Overview. Available at: https://www.encyclopedia.com/environment/encyclopedias-almanacs-transcripts-and-maps/war-and-warriors-overview (accessed: 20.11.2018).

24. Machnik J. Studia nad kulturą ceramiki sznurowej w Małopolsce. Wrocław - Warszawa - Kraków, 1966, pp. 191-234.

25. Machnik J. 2004. Pasterstwo u społeczeństw kultury ceramiki sznurowej w dorzeczu górnej Wisły, górnego Bugu i Dniestru. In: Nomadyzm a pastoralizm w międzyrzeczu Wisły i Dniepru, Archeologia Bimaris: Dyskusje vol. 3. Poznań, 2004, pp. 137-144.

26. Machnik J., Bagińska J., Koman W. Neolityczne kurhany na Grzędzie Sokalskiej w świetle badań archeologicznych w latach 1988-2006. Kraków, 2009, pp. 9-214.

27. Meyer C., Brandt G., Haak W., Ganslmeier R.A., Meller H., Alt K.W. The Eulau Eulogy: Bioarchaeological Interpretation of Lethal Violence in Corded Ware Multiple Burials from Saxony-Anhalt, Germany. In: Journal of Anthropological Archaeology, 2009, no. 28, pp. 412-423. 
28. Mizoguchi K. Time in the reproduction of mortuary practices. In: World Archaeology, 1993, vol. 25 (2), pp. 223-235.

29. Molloy B., Grossman D. Why can't Johnny kill? The psychology and physiology of interpersonal combat. In: The Cutting Edge: Studies in Ancient and Medieval Combat, Stroud, 2007, pp. 188- 202.

30. Neubert, A., Wicke, J., Bruchhaus, H. Mit der Axt - durch die Axt. Der Zusammenhang von Schädeldefekt und Waffenbeigabe in Bestattungen des schnurkeramischen Kulturkreises. In: Link, T., PeterRöcher, H. ed. Gewalt und Gesselchaft. Dimensionen der Gewalt in ur- und frühgeschichtlicher Zeit. Bonn, Habelt, 2014.pp. 217-224.

31. Otterbein K. Anthropology of War. Long-Grove, Waveland Press Inc. Publ., 2009, pp. 1-110.

32. Petrosyan A. Armenian traditional Black Youths: the earliest sources. In: Journal of Indo-European Studies, 2011, no. 39, pp. 342-353.

33. Razumov S.M. Flint Artifacts of Northern Pontic Populations of the Early and Middle Bronze Age: 3200-1600 BC. In: Baltic-Pontic Studies, 2011, vol. 16, pp. 147-153.

34. Sanders A. Warriors, Anthropology of. In: Kurtz L. red. Encyclopedia of Violence, Peace, and Conflict. 2008, pp. 2432-2442.

35. Schulting R. War without Warriors? The Nature of Interpersonal Conflict before the Emergence of Formalized Warrior Elites. In: The Archaeology of Violence. Interdisciplinary Approaches. New York, State University of New York, 2013, pp. 19-36.

36. Skrzyniecki R. Problem genezy zorganizowanej przemocy w świetle źródeł archeologicznych. In: Folia Praehistorica Posnaniensia, 2015, vol. 20, pp. 449-470.

37. Skrzyniecki R. Wojownicy społeczności kultury ceramiki sznurowej w Europie Środkowej w III tys. przed Chr., typescript of a doctoral thesis. 2018.

38. Sofaer-Derevenski J. Age and gender at the site of Tiszapolgár-Basatanya, Hungary. In: Antiquity, 1997, vol. 71 (274), pp. 875-889.

39. Sørensen M.L.S. Stating identities: the use of objects in rich Bronze Age Graves. In: Explaining Social Change: Studies in Honour of Colin Renfrew. Cambridge, McDonald Institute for Archaeological Research Publ., 2004, pp. 167-176.

40. Suchowska P., Skrzyniecki R. Opowieść o chwale i mieczu. Kilka uwag o wojnie i wojownikach w epoce brązu. In: Vir Bimaris. Od kujawskiego matecznika do stepów nadczarnomorskich. Studia z dziejów międzymorza bałtycko-pontyjskiego ofiarowane Profesorowi Aleksandrowi Kośko, Archeologia Bimaris. Dyskusje, 2019, vol. 5, pp. 813-827.

41. Thorpe I.J.N. Anthropology, Archaeology and the origin of warfare. In: World Archaeology, 2003, vol. 35, pp. 145-165.

42. Thorpe I.J.N. The ancient origins of warfare and violence. In: Warfare, violence and slavery in prehistory: proceedings of a Prehistoric Society conference at Sheffield University (BAR International Series, vol.1374). Oxford, Archaeopress, 2005, pp. 1-18.

43. Turek J. Social and symbolic foundations of the Beaker Phenomenon. In: Besse M. ed. Around the PetitChasseur Site in Sion (Valais, Switzerland) and New Approaches to the Bell Beaker Culture. Proceedings of the International Conference (Sion, Switzerland - October $27^{\text {th }}-30^{\text {th }}$ 2011). 2014, pp. 285-293.

44. Vandkilde H. Warfare and Gender According to Homer: An Archaeology of an Aristocratic Warrior Culture. In: Warfare and Society. Archaeological and Social Anthropological Perspectives. Aarhus, Aarhus University Publ., 2006, pp. 515-528.

45. Vandkilde H. Warriors and Warrior Institutions in Copper Age Europe. In: Warfare and Society. Archaeological and Social Anthropological Perspectives, Aarhus, Aarhus University Press, 2006, pp. 393-422.

46. Vandkilde H. Warfare in Northern European Bronze Age Societes: Twentieth-Century Presentations and Recent Archaeological Research Inquiries. In: The Archaeology of Violence. Interdisciplinary Approaches, IEMA Proceedings vol. 2. New York, State University of New York, 2013, pp. 37-63.

47. Westermann J. Stepping From Male to Warrior Identity. Male Identity in Late Neolithic/Early Bronze Age Europe, 2800-2300 BC. In: Archaeologia Baltica, 2007, no. 8, pp. 22-31.

48. Wiermann R.R. An anthropological approach to burial customs of the Corded Ware culture in Bohemia. In: Benz M., van Willingen S. eds. Some Approaches to the Bell Beaker Phenomenon. Lost Paradise...? Proceedings of the 2nd Meeting of the „Association Archéologie et Gobelets", Feldberg (Germany), 18th-20th April 1997, BAR International Series 690. 1998, pp. 129-140. 
49. Wiermann R.R. Zur Sozialstruktur der Kultur mit Schnurkeramik in Böhmen. In: Vom Endneolithikum zur Frühbronzezeit: Muster sozialen Wandels? (Tagung Bamberg 14-16 Juni 2001, Universitätsforschungen zur prähistorischen Archäologie. vol. 90). Bonn, Dr. Rudolf Habelt GmbH. Publ., 2002, pp. 115-131.

50. Włodarczak P. Pochówki dzieci w kulturze ceramiki sznurowej na przykładzie cmentarzysk z Wyżyny Małopolskiej. In: Dusza maluczka, a strata ogromna (Funeralia Lednickie. Spotkanie 6). Poznań, 2004. pp. 341-351.

51. Włodarczak P. Kultura ceramiki sznurowej na Wyżynie Małopolskiej. Kraków, 2006, pp. 13-165.

\section{ACKNOWLEDGMENTS}

Research funded by the National Science Centre, Poland ("Preludium" project no. NCN 2016/21/N/ HS3/00047; title: "Reconstruction of cultural and biological dimensions of warriorhood in Corded Ware Culture communities of Lesser Poland”).

\section{БЛАГОДАРНОСТИ}

Исследование выполнено при финансировании Национальным научным центром Польши (проект” Preludium “no. NCN 2016/21/N/HS3/00047: “Реконструкция культурных и биологических измерений воинской доблести в общинах культуры шнуровой керамики Малой Польши”).

\section{INFORMATION ABOUT THE AUTHORS}

Skrzyniecki Rafat - PhD, Adam Mickiewicz University in Poznań, Department of History, Poznań; e-mail: rskrzyniecki@gmail.com

Skrzyniecka Weronika - MA, Adam Mickiewicz University in Poznań, Department of Archaeology, Poznań;

e-mail: wskrzyniecka@gmail.com

\section{ИНФОРМАЦИЯ ОБ АВТОРАХ}

Рафал Скржинецкий - доктор истории, исторический факультет Университета имени Адама Мицкевича, Познань; e-mail: rskrzyniecki@gmail.com

Вероника Скржинецка - аспирант, факультет археологии Университета имени Адама Мицкевича, Познань;

e-mail: wskrzyniecka@gmail.com

\section{FOR CITATION}

Skrzyniecki R., Skrzyniecka W. The ,i” of a warrior. Social complexity and cultural recognition of warrior virtues in the corded ware culture. In: Bulletin of the Moscow Regional State University. Series: History and Political Sciences, 2020, no. 5, Circumpontica, iss. II, pp. 89-105.

DOI: $10.18384 / 2310-676 \mathrm{X}-2020-5-89-105$

\section{ПРАВИЛЬНАЯ ССЫЛКА НА СТАТЬЮ}

Скржинецкий Р., Скржинецка В. Личность воина. Социальная стратификация и оценка воинских доблестей в мире культур шнуровой керамики // Вестник Московского государственного областного университета. Серия: История и политические науки. 2020. № 5. Циркумпонтика. Вып. II. C. 89-105.

DOI: $10.18384 / 2310-676 \mathrm{X}-2020-5-89-105$ 